\title{
Road Investment and Regional Development Some Evidencies from Albania
}

\author{
Dr. Ing. Alma Golgota \\ Engineering Science Dept. - University of "A. Moisiu”,,Durres,Albania \\ almagolgota@uamd.edu.al; almagolgota@yahoo.com
}

Phd Cand. ing. Diana Bardhi

Politecnic University, Tirana, Albania

\begin{abstract}
The purpose of this paper is to present an overview of current regional development and the forecast of the economic impact of transport (roads). Investment in Infrastructure (especially Roads) has for sure a very positive impact on regional development. The most common classification economic indicator of a country is Gross National Product per Capita. In fact income is an important criterion with the respect of the regional development. Investment in transport lead to general changes, which should be easily determine as direct and indirect benefit like reducing travel time, operating cost, increasing transport safety, but the contribution to regional development as a whole is subject of certain debates. There are some basically opinions about relation which exist between transport infrastructure and regional development. The first one states that infrastructure hardly influence the regional economic development. The second opinion is maybe the most acceptable one, that interaction between infrastructure and economic development is not a "linear" relationship. The third one is that regional development could be influenced easily by infrastructure investment. When analyzing recent development strategies, it can be accepted that the Republic of Albania is supporting the thesis that building infrastructure network is a prerequisite of regional development. In that context, Government investments in the regional and rural program are elaborated with expected positive effects on reduction of poverty and regional development. In this paper the case study of the "Kukes- Morine " road that will improve transport connections is selected in order to determine whether or not there is a justification for such belief.
\end{abstract}

Keywords: Infrastructure, transport, regional development, Albania

\section{Introduction}

The provision of good quality infrastructure ${ }^{1}$ is often cited as the most important factor of local and regional development, through which the adequate conditions for the growth of new business and attraction of firms to less developed areas are provided. At the same time, the impact of infrastructure development on local and regional development is the subject of various discussions. For a long time, in a relevant literature there was a generally accepted belief that this relationship has a positive direction, i.e. " it happened after it was built so it must be because of it" (Judge, 1998). But recent studies, such as Goodwin's (2000) demonstrate that this argument is questionable and that, especially in the context of the European Union's (EU) regional policy, a revision of this assertion is needed. The aim of this paper is to present a theoretical approach to the link between transport infrastructure and regional development, followed by empirical evidence based on the Albanian example. In the first part we focus on the relationship between regional development and infrastructure. The second part is devoted to a narrower description of transport infrastructure and its potential effects on the encompassing area. The example of the interaction between transport infrastructure and regional development in the case of motorway building and the Kukes region is provided in the third part. The paper ends with concluding remarks. 


\section{Infrastructure and Regional Development}

Regional inequalities with diversified regional development are foreseen as a reality of all national as well as European Union policies ${ }^{2}$. Traditionally, regional economics has explained income differences on the basis of differences between regions in their endowments of natural resources, factors of production, infrastructure and technology. In that context, the removal of obstacles to the movement of goods and factors would itself cause convergence of factor returns and living standards. Underdeveloped infrastructure can be considered as important obstacle to the regional development, and its improvements should spur the economic growth in the region.

1.Infrastructure is usually understood as basic public infrastructure, which forms the foundation for society and economics. As it is mentioned in World Bank report (2004): infrastructure is an umbrella term for many activities, it plays a very important role for industrial and overall economy.

2 Nearly one quarter of the EU citizens live in regions eligible to receive assistance under Objective 1 of the Structural Funds, the main instrument of the EU regional policy. Recent analyses demonstrate that convergence.

This notion is well recognized in the relevant theoretical literature.

Richardson and Jensen (2000) indicate that spatial differences in the EU cannot be reduced without a fundamental improvement of transport infrastructure and services to and within the regions where a lack of access to transport and communications infrastructure restricts economic development. Improvements of accessibility are seen as a critical priority in the development of the polycentric urban systems ${ }^{3}$ and precondition for inclusion of economic development within an overall spatial strategy of harmonization.

At the beginning of the 1980s a scientific approach to infrastructure in the frame of economic development was initiated 4 . The reason for this is that standard cost benefit analysis (CBA), as an evaluation tool, considered only the direct benefits of infrastructure investments omitting a whole set of externalities. Additionally, many initiatives undertaken by the World Bank and similar organizations and institutions that promote economic development by investing into infrastructure projects have fulfilled their goals, although those investments did not achieve all the foreseen results.

Many project-oriented studies were undertaken to investigate the role of economic and social impacts of transport infrastructure on the monitored area. To mention some of them, Harris (1974) performed a study on the impact of alternative motorway routes in regional development. Delayque (1969) conducted a study on the impact of motorway building on the development of the Rhone valley and Simmons (1991) on the impact of the Channel Tunnel on regions in France and England.

A study by Goodwin (2000) is among the first that thoroughly investigated the role of investment in transport infrastructure and the benefits accruing from them. Goodwin has analyzed reports from The Standing Advisory Committee on Trunk Road Assessment (SACTRA) and concluded the following:

3 The European Spatial Development Perspective (ESDP) has found polycentricity as an answer to the more balanced development. The ESDP promotes polycentricity at the EU level, firstly, to ensure a more regionally balanced development and, secondly, to enhance the EU competitiveness in the world market.

4 An overview of research dedicated on the effectiveness of public infrastructure versus private initiatives and its impact on regional development through production function can be found in a paper written by Rovolis and Spence (1998). See also Biehl (1986), Batten and Karlsson (1996), Banister and Berechman (2000) and Rietveld and Bruinsma (1998).

-

There are no automatic economic or employment benefits from new transport projects.

Actually, some projects may even be harmful;

For projects that produce economic benefits, the more economically deprived end of 
the link may still experience greater economic costs than benefits;

- $\quad$ Cost benefit analysis as currently undertaken fails to elaborate the true economic impacts;

- The link between transport growth and economic growth can be broken and especially in the cases when charges (tools) are levied to correct market distortions.

Based on Goodwin's research it can be generally concluded that while taking an infrastructure investment it is incorrect to intuitive assume positive interaction with regional development.

For the future of the EU infrastructure projects, the EU (2002) has issued a revised edition of its guidance on the application of CBA to infrastructure projects that is more thoroughly requesting analysis, among other, upon impacts on regional development.

\subsection{Complexity of Infrastructure and Development}

As it was stated in the previous part, it is unequivocal that infrastructure has an impact on economic development. According to Padjen (1996) there are three theories that explore the relationship between infrastructure and development:

- $\quad$ Development through a surplus of infrastructure;

- $\quad$ Development through a deficit of infrastructure;

- $\quad$ Balanced development.

When infrastructure capacity is higher than production, it is assumed that infrastructure will have an initial and inductive role in economic development. The rationale behind this approach is that the existence of infrastructure is a prerequisite for the development of other activities. This concept is still used in less developed countries, as well as in Albania, which will be elaborated in the forthcoming parts. However, experience has shown that physical infrastructure, i.e. objects may guarantee economic development.

If economic growth is based on development, the growth of production, as a logical link a pressure to invest into new infrastructure, will be created. The idea is that production will speed up investments into infrastructure and create growth potentials. Of course, a minimum of existing infrastructure is requested. This approach is usually applied in developed countries.

Balanced development is focused on the idea that only the simultaneous development of infrastructure and production is sustainable, explaining that infrastructure is an integral part of production chain and its function is economic growth.

These theories also provide the framework for analyzing the link between the transport infrastructure development and regional development. We thereby proceed with reviewing the literature on indicators of transport infrastructure.

\section{Transport Infrastructure}

Transport infrastructure has a specific role in regional development. For a long time it was assumed that transport infrastructure has only a positive impact on regional development.

However, the role of transport infrastructure on regional development is evaluated through direct but also indirect effects, albeit whether they are positive or negative ones. Here, we only briefly discuss direct and indirect effects.

\subsection{Direct Effects}

Building of transport infrastructure directly influences transport costs ${ }^{5}$. These changes are followed by a decrease in fuel consumption, capital consumption as well as a decrease of the related compensations for employees. Changes are followed by changes in transport mode, transport route, time horizon and accessibility of movements within the region. (Ladavac,1999) 
Reduction of transport costs combined with migration changes of households and business location leads to the increased productivity of the regions. Within households, decrease in travel times leads to the achievement of the same level of productivity but also consumption in a shorter time. It also stimulates elasticity relating to the migration process. Within the business sector, transport improvements lead to the effectiveness of production and positive impact on the 'just in time' principle. In the labour market, commuting time is significantly reduced.

Reduction of transport costs also leads to the increased accessibility of the region. Increased productivity and increased regional accessibility could impose an increase of economic activity. Vickerman (1991) summarizes such effects into two groups: 1. Objectively measured effects, reflecting changes in inputs and outputs of industries due to the changes in transport and 2. Subjective effects referring to changes in the perception of a region.

\subsection{Indirect Effects}

Indirect impact of building of transport infrastructure can be analyzed through changes of attractiveness of the monitored region, size of movement of goods and services and changes in the size of transport costs, i.e. changes in relative competitiveness of the regions. In addition to these changes, indirect effects also refer to changes in the environment, i.e. noise, air pollution, changes in the landscape, etc.

If the region is less developed, under indirect effects another two categories of impacts are considered; impacts on income and impacts on capacity.

Impacts on income are impacts derived from the time travel savings and reductions in vehicle operating costs, which directly influences the size of transportation costs. Within this category alone indirect benefits from the development changes within the region are considered, such as improvements from the building of new or improved existing infrastructure.

Impacts on capacity refer to the increase of regional production capacities. For example, increased transport capacity can increase the export potential of the monitored regions.

Within developed regions, changes in transport may bring only marginal benefits so transport improvements have the greatest impact when they remove a former bottleneck. $(E C, 1996)$

5. The traditional approach to the evaluation of the building of a new motorway usually focuses on reductions in journey times, increased safety and reduction in vehicle operating costs.

Nijkamp et al (2002) have summarized the basic effects of motorway building as shown in the following Table 1:

Table 1. Impacts of motorway building

\begin{tabular}{|l|l|l|}
\hline Transport economics & Effects on environment and landscape & Effects on regional development \\
\hline \hline $\begin{array}{l}\text { increased travel safety } \\
\text { increased in journey travel } \\
\text { increased in travel comfort }\end{array}$ & $\begin{array}{l}\text { landscape } \\
\text { air polution } \\
\text { water polution }\end{array}$ & $\begin{array}{l}\text { development } \\
\text { employment increase } \\
\text { effects on trade, industry and tourism }\end{array}$ \\
$\begin{array}{l}\text { reduced operating costs } \\
\text { lower maintanance cost } \\
\text { user benefits }\end{array}$ & $\begin{array}{l}\text { change landscape } \\
\text { conservation of nature } \\
\text { Land development }\end{array}$ & \\
\hline
\end{tabular}


Source: Nijkamp, P., Ubbels, B., Verhoef, E. (2002): "Transport Investment Appraisal and the Environment", Tinbergen Institute Discussion Paper TI 2002-104/3.

In 1996, the European Commission Directorate General for Transport issued a manual on methodologies for transport impact assessment that also includes impact on regional development (EC, 1996). According to this, APAS methodology (Action de Promotion, d'Accompagnement et Suivi et autres activites), impacts of transport infrastructure on regional development can be seen through:

- $\quad$ direct effects - analyzed through changes in employment,

- $\quad$ induced effects - changes in the accessibility character of a region, and

- $\quad$ catalyst effects - impact on other policy instruments.

All three effects are analyzed on different spatial levels, time framework and sectors

(see Table 2-4).

Table 2 Socio-economic impacts of new motorway on different spatial levels

\begin{tabular}{|l|l|l|l|}
\hline & Local level & Regional level & National level \\
\hline \hline Direct Effects & $\begin{array}{l}\text { Increased Employment in } \\
\text { Construction Sector }\end{array}$ & $\begin{array}{l}\text { Wide service sector employment } \\
\text { due to multiplier effect }\end{array}$ & \\
\hline Induced Effects & $\begin{array}{l}\text { Increased office rents close } \\
\text { to new interchanges }\end{array}$ & $\begin{array}{l}\text { Decentralization of households } \\
\text { into areas with enhanced } \\
\text { accessibility }\end{array}$ & $\begin{array}{l}\text { Increased competitiveness of } \\
\text { firms because of reduced } \\
\text { travel costs }\end{array}$ \\
\hline Catalyst Effects & $\begin{array}{l}\text { Increased business } \\
\text { employment due to } \\
\text { enhanced perception of }\end{array}$ & & \\
\hline
\end{tabular}

Source: European Commission (1996): "APAS - Methodologies for transport impact assessment". Luxembourg: Office for Official Publications of the European Communities.

Table 3 Socio-economic impacts of new motorway at different temporal levels

\begin{tabular}{|l|l|l|l|}
\hline & Short term & Medium term & Long term \\
\hline \hline Direct Effects & $\begin{array}{l}\text { Increased Employment in } \\
\text { Construction Sector }\end{array}$ & & \\
\hline Induced Effects & $\begin{array}{l}\text { Some anticipatory relocation of } \\
\text { households into improved corridors }\end{array}$ & $\begin{array}{l}\text { Some agglomeration of firms } \\
\text { close to interchanges }\end{array}$ & $\begin{array}{l}\text { Further movements of } \\
\text { firms and households, } \\
\text { away from area due to } \\
\text { congestion and high } \\
\text { rents }\end{array}$ \\
\hline Catalyst Effects & $\begin{array}{l}\text { Additional employment in } \\
\text { landscaping projects }\end{array}$ & & \\
\hline
\end{tabular}

Source: European Commission (1996): "APAS - Methodologies for transport impact assessment". Luxembourg: Office for Official Publications of the European Communities.

Based on the APAS methodology, in the following part of the paper we will analyze the impact of the motorway construction on the regional development in the case of Albania. 


\section{An Albanian Case Study}

Before 1990s Albania didn't use appraisal techniques to assess the impacts of transport infrastructure on development. In 1994, the first study on the social and economic impacts of motorway building in Albania was produced, while nine years later methods of capital budgeting for road building were systematized and obligatory applied in a project analysis. In 2003 a project called "Motorway Kukes- Morine " was the first study that included indirect benefits assessment of its building, and it also investigated demographic and economic factors. Another important year was 2008 when a classification of rural and regional roads, based on RED (road economical decision) in Albania was produced by ADF in co-operation with Roughton Int company, and with the approval of the World Bank. In the following years, studies on the direct and indirect impacts of road building have become an integral part of technical documentation.

In 2009 the Albanian Development Fund and the Roughton Int, have produced a study on cost benefit analysis of $3000 \mathrm{~km}$ regional and rural roads, which also set up a framework for the implementation of them as model in Albania. Today, a revision of the CBA study has being made.

On gaining its independence, the Albanian transport system could be described as recuperated after 2005, being linked, but showing some maintained infrastructure problems.

Fig. 1 Distribution Map of the regional and rural roads to be financed by WB, EIB, IBRD, OPEC, OFID, KfW, IPA and Albanian Government

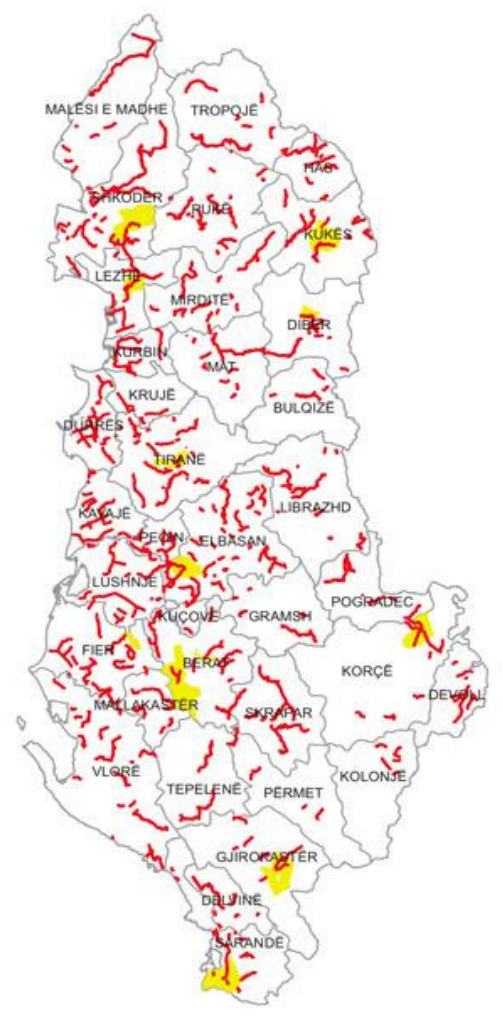

However, transport development strategies attitude towards the role of transport infrastructure, and in particular road infrastructure in the context of regional development, has significantly changed. Today, building of road infrastructure and transport policy in general is seen as a main factor for the cohesion of Albania territory, within European space. As an example, the action plan for motorway and regional roads building and their maintenance (Kukes Morine 2009) are explicitly 
proclaiming that intensive investments in building of motorway - regional roads network which are seen as the main factor that will improve territorial cohesion of Albania.

Roads, paved (\% of total roads)

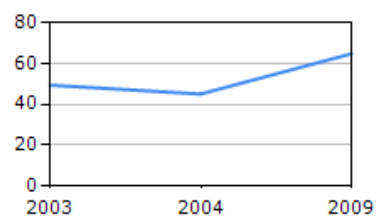

World 64.9 (2009)

Source:WDI and GDF 2010

\subsection{Kukes Morine Motorway}

Since the end of the Kosovo War of 1999, hundreds of thousands of Albanians have passed through the poor old mountain road to get to Albania's beaches. Building a highway would "crystallize a year-round tourism industry and double the size of the Albanian market", while allowing both communities to rationalize agriculture. Travel times are expected to be lowered to two and a half hours or less, down from seven.

Once finalized, the project will link the Adriatic Sea with the Pan-European corridor $X$ at the E80 near the town of Merdar between the contested Kosovo-Serbia border.

In 2009 the highway Kukes Morine were substantially completed. During summer 2011 the whole project was finished. It is expected that the motorway will become a toll highway to cover the costs of maintenance.

This road provides Kosovo with Albania and the Adriatic coast. It was also associated with a similar project in Kosovo, Merdare highway Vermicelli, currently under development.

Kukes is an important district on north- east of Albania, and Durres the most popular touristic place in Albania which has been used from Kosovo population, so a high quality transport network is a major priority.

The construction of the motorway has started in 2007. It is a four lane highway being built since 2007 by the AmericanTurkish consortium Bechtel-ENKA between Albania and Kosovo. At present, the highway starts at Thumane, Albania and ends at Duhel, Kosovo. Ultimately, the highway will start at Lezhe, Albania and end at the E75/Corridor X in Doljevac near Nis, Serbia as part of the South-East European Route 7. Once the Kosovo part of the project is completed, the motorway will link the Adriatic Sea ports of Durres and Shengjin in Albania with the Pan-European corridor X in Serbia through Pristina, Kosovo.

Dubbed the "patriotic highway," the project links Albanians in Kosovo and Albania, helping to boost cultural and economic ties. The project is Albania's largest in decades, costing 826 billion euros the highway and 280 billion euro the longest tunnel $5.6 \mathrm{~km}$ in Balkan, making travel and trade easier for the hundreds of thousands of Kosovo Albanians vacationing in Albania during the summer holidays and for business. It was projected for a 1500 vehicles to be loaded daily, but during the summer passed around 12000 vehicles.

Generally, the motorway Kukes- Morine reduces the distance from many Kosovo towns to Albania. As the presented data reveal tourist did not come more to the region just because of the infrastructure improvement. In addition, when tourists make decisions about destinations, there are many different factors that might have impact on their choice. If we analyze only the recent years, the index of tourist arrivals from Belgium, Denmark, France, the Netherlands, countries that are quite far away from Albania, were higher than average; thereby we can conclude that the motorway had a positive impact on the tourism sector, particularly for tourists from distant countries. New roads also augment attractiveness of undiscovered country coast for neighbours primarily, Italian Slovenian, Czech, English tourists who come for one - two days.11

11 For the more detailed research we need additional data that are not available at the moment.

Due to that situation I performed a small research on terrain and found that some mountain houses turned into hotels or restaurants are increasing their activity and in some villages inside Kukes, Tropoja town after the building of the motorway. However, since those data are not officially published and substantiated by the longer research studies, we consider them only as a preliminary confirmation of my assumptions, and not as firm evidence. 
In my opinion, new infrastructure also increases the attractiveness of the entire county, because the prices of real estate on the coast have been growing approximately $8 \%$ per year, while inside the region, the mentioned index was increased by $150 \%$ and more during last seven years. Although, many data which can prove the statement of the positive impact of the motorway on the Kukes Morine tourism sector are not official, we consider that there is an intensive and favorable relationship.

\section{Concluding Remarks}

With a general assumption that building of motorway network has an impact on the region that is encompasses, the aim of this paper was to envisage to what extent this assumption can be validate in the Albania case.

We have chosen to analyze the case of motorway Kukes Morine, because effects of its construction are dominantly distributed on all touristic regions of Albania. Before motorway building, existing road network was such that there wasn't a good connection between cities in the County. However, during the summer there were severe congestion problems and, even more, problems regarding, long time of journey, security of pedestrians since the main regional road was going along the mountains, far away from tourist destinations of the Adriatic- Jon coast line and the Ports. In that context it was to build a new road - motorway, with the two main goals: the first shorten the distance and the time of the tourist to reach the Albanian coast and the second one to increase accessibility of other Eastern Country to stimulate the movement of vehicles by road to Durres seaport. Construction of the motorway has started with the project since in 2003 up to 2009-2011 170 $\mathrm{km}$ out of 170 kilometers have been built and put into operation. After a decade a general conclusion is that the building of the motorway Kukes- Morine has directly contributed to the reduction in the journey time and in that sense reduction in the vehicle operating costs. Regarding number of accidents it is also notable that building of the new motorway has contributed to the significant reduction in the number of accidents.

As our analysis has confirmed, and based on the APAS methodology, building of motorway has an impact on the employment and especially within the construction sector. Furthermore, a positive interaction related to better accessibility through motorway network and tourism is verified. There are also particular trends, such as a huge increase of real estate prices but it is very difficult to extract to which extent it is due to the perception of better transport accessibility or to the exceptional increase in demand.

\section{References:}

- Batten, David F. and Karlsson. Charlie ( 1996) "Infrastructure and the complexity of Economic Development". Heidelberg: Springer- Verlag

- Brunisma, F.R ( 1995)"The impact of new infrastructure on Spatial Patterns of Economic activities" Proceeding from $35^{\text {th }}$ Congress of European Regional Science Association, Odense.

- David and Berechman, Joseph( 2000): "Transport Investment and Economic Development" London UCL press

- European Union Road Federation ( 2006b); "The socio-Economic benefits of Roads in Europe" Brussels: ERF

- European Union (2002):" Guide to Cost-Benefit Analysis of investment projects"

- Reitveld, Piet and Bruinsma, Frank (1998): "Is Transport Infrastructure effective?” Transport Infrastructure and Accesibility: Impact on the Space Economy"

- World Bank Report Progress 2011. 